PROCEDIA

Studi Kasus dan Intervensi Psikologi

ISSN:2302-1462

Volume 8(1) 1-8, Maret 2020

DOI: $10.22219 /$ procedia.v4i1.11965

\title{
Solution focused therapy untuk memperbaiki pola komunikasi keluarga
}

Tia Safira, Universitas Muhammadiyah Malang, Malang, Indonesia

Korespondonesi:

Tia Safira, Universitas Muhammadiyah Malang, Malang, safira.tya@gmail.com

\section{Riwayat artikel \\ Naskah diterima: \\ 08/09/2019}

Revisi diterima:

11/12/2019

Naskah disetujui:

$15 / 02 / 2020$

\begin{abstract}
Abstrak
Keluarga adakalanya mengalami suatu permasalahan yang terkait dengan pola komunikasi. Dampak pada permasalahan dengan pola komunikasi yang tidak sehat ini yaitu tidak ditemukannya solusi dari permasalahan yang dialami oleh keluarga karena mengalami sequence of interaction dan tidak pernah ada proses diskusi di dalamnya. Asesmen yang dilakukan pada keluarga berupa interview dan observasi kepada ayah, ibu, dan anak. Hasil asesmen menunjukkan bahwa keluarga tidak dapat membangun solusi dari masalah yang mereka hadapi. Intervensi yang diberikan adalah Solution Focused Therapy yang disusun sebanyak 6 sesi terapi. Tujuan pemberian intervensi ini agar keluarga merubah pola komunikasi mereka menjadi lebih sehat. Hasil dari pemberian intervensi ini keluarga berhasil menyusun beberapa solusi dan merubah pola komunikasi mereka.

Kata kunci: Solution Focused Therapy, merubah pola komunikasi.
\end{abstract}

\section{Latar Belakang}

Keluarga merupakan suatu sistem dengan unit-unit yang saling berinteraksi (Goldenberg \& Goldenberg, 1985). Keluarga adalah sistem emosional yang secara organisatoris kompleks yang mungkin terdiri dari beberapa generasi. Apakah pasangan hidup yang tradisional atau inovatif, adaptif atau maladaptif, efisien atau terorganisir secara kacau, menikah atau berkomitmen dengan atau tanpa anak-anak, keluarga mau tidak mau, dengan berbagai tingkat keberhasilan, untuk mengatur dirinya menjadi fungsional atau memungkinkan kelompok mungkin sehingga dapat memenuhi kolektif atau bersama-sama didefinisikan kebutuhan dan tujuan tanpa secara konsisten atau secara sistematis mencegah anggota tertentu dari memenuhi kebutuhan dan tujuan masing-masing (Kantor \& Lehr, 1975). Keluarga biasanya mengembangkan aturan yang menguraikan dan mengalokasikan peran dan fungsi anggotanya. Mereka yang hidup bersama untuk waktu yang lama, dan mengembangkan pola yang disukai untuk bernegosiasi dan mengatur hidup mereka untuk memaksimalkan harmoni dan prediktabilitas (Le Poire, 2006).

Tidak semua keluarga menampilkan pola yang stabil, kolaboratif, terarah, dan berulang urutan interaktif. Pertukaran nonverbal antara anggota keluarga, khususnya, merepresentasikan transaksi kode yang halus yang mentransmisikan aturan dan fungsi keluarga yang mengatur 
berbagai perilaku yang dapat diterima ditoleransi oleh keluarga (misalnya, bahwa seorang putra tidak berbicara di hadapan ibunya berbicara, dan dia sendiri dapat mengambil gilirannya hanya setelah suaminya berbicara). Seperti itu Interaksi berpola adalah pola transaksional yang dapat diprediksi secara bersama-sama dihasilkan oleh semua anggota keluarga dengan isyarat, seolah-olah setiap peserta merasa terpaksa memainkan bagian yang terlatih baik, suka atau tidak suka (Goldenberg \& Goldenberg, 2012).

Komunikasi adalah hal yang sangat penting dalam lingkungan keluarga. Pembentukan komunikasi intensif, dinamis dan harmonis dalam keluarga tentu menjadi dambaan setiap keluaraga. Komunikasi keluarga adalah suatu pengorganisasian yang menggunakan kata-kata, sikap tubuh intonasi suara tindakan untuk menciptakan harapan image, ungkapan perasaan serta saling membagi pengertian. Komunikasi yang terjalin antara orangtua dan anak dalam satu ikatan keluarga di mana orangtua bertanggung jawab dalam mendidik anak (Koerner \& Fitzpatrick, 2006). Konsep teori sistem keluarga digunakan dengan meluas untuk menerangkan kefungsian keluarga khususnya berkaitan hubungan di antara ibu bapak dan anak di mana interaksi kompleks yang berlaku dalam keluarga dan juga faktor yang mempengaruhi proses keluarga membuat keputusan dan menetapkan pencapaian tertentu (Bigner, 2002).

Gaya komunikasi adalah suatu cara atau kekhasan yang digunakan seseorang dalam berkomunikasi saat menyampaikan gagasan, ide dalam bentuk verbal maupun non verbal dengan orang lain.Salah satu jenis gaya komunikasi adalah gaya komunikasi otoriter. Gaya ini bersifat satu arah dan mutlak, yaitu komunikasi satu arah dari orangtua kepada remaja saja, atau kendali remaja mutlak di tangan orang tua. Tipe orang tua dengan gaya ini menjadi controller terhadap pendapat anak, sangat sulit menerima saran dan cenderung memaksakan kehendak ketika mengalami perbedaan sehingga tidak pernah terjadi diskusi penyelesaian masalah (Gamble \& Gamble, 2005).

Dalam kasus ini, keluarga mengalami permasalahan terkait dengan interaksi komunikasi antar anggota keluarga. Ibu memiliki gaya komunikasi yang selalu bersikap keras kepada siapapun, lalu ayah memiliki gaya komunikasi yang cenderung berkebalikan dengan istri terutama di dalam menghadapi anak, sementara anak adalah tipe anak pemberontak yang mudah melawan orang tua apabila mengalami perbedaan pendapat diantara ketiganya. Permasalahan yang terjadi adalah ibu selalu mengatur kehidupan anak dan memaksakan kehendaknya pada si anak sementara ayah berusaha untuk menenangkan istrinya namun terkadang cara yang dilakukan ayah yaitu dengan berkata kasar pada ibu.

\section{Metode Asesmen}

Metode yang digunakan dalam asesmen dan pengambilan data adalah observasi dan wawancara. Observasi dilakukan saat wawancara, kegiatan subjek sehari-hari dirumah dan juga anaknya, tujuan observasi adalah untuk melihat pola perilaku dan keseharian keluarga dalam segala situasi dan keadaan. Wawancara dilakukan kepada 3 anggota keluarga yang bermasalah yaitu ayah, ibu, dan anak dengan tujuan untuk mengetahui lebih dalam terkait dengan data dan juga dinamika terbentuknya permasalahan keluarga yang dialami oleh keluarga.

\section{Presentasi Kasus}

Berdasarkan hasil wawancara yang telah dilakukan, diketahui permasalahan yang keluarga alami adalah berawal dari anak memutuskan untuk menikah dengan seorang tentara berpangkat kopral yang bertugas di kota Malang. Rencana pernikahan tersebut sempat ditolak oleh ibu dan ayah dengan alasan bahwa pangkat calon suami anaknya hanya kopral dengan gaji yang tidak terlalu tinggi. namun anak tetap bersih keras untuk menikah dengan suaminya hingga ayah dan ibu tidak bisa mencegahnya lagi. Namun dalam hal pernikahan ini, ayah lebih lebih mengembalikan semua keputusan kepada anaknya. Setelah pernikahan berlangsung, anak dan suami untuk 
sementara bertempat tinggal di rumah ayah dan ibu. Ketika suami dari anaknya bekerja, ibu sering bertindak semena-mena kepada anak dengan cara menyuruhnya dengan kasar untuk membersihkan seluruh rumah, pakaian kotor, dan juga cucian piring. Dalam proses ini, anak kerap kali menolak karena merasa capek karena saat itu anak masih aktif berkuliah sehingga merasa tertekan dengan perlakuan ibunya. Ayah berusaha menenangkan ibu ketika sedang marah bahkan terkadang dengan mengeluarkan kata-kata kasar kepada ibu, sayangnya sikap ayah yang seperti itu membuat ibu semakin marah kepada anaknya. Selang satu bulan berlalu, anak hamil dan selama masa kehamilan ibu tidak menunjukkan sikap yang semena-mena, hanya lebih membiarkan anak untuk melakukan apa saja. Dengan sikap ibu yang kurang perhatian selama masa kehamilan itu, anak kerap kali memprotes ibunya sehingga masalah kembali timbul. Dari hasil interview diketahui bahwa sikap ibu yang selalu menolak untuk menuruti saran dan kemauan ayah karena ibu menganggap ayah adalah orang yang tidak berkompeten dalam hal apapun serta tidak berpendidikan sehingga segala sesuatu yang ayah sarankan bagi ibu adalah hal yang tidak bermakna dan tidak dapat dipertanggungjawabkan. Sementara dari pihak ayah merasa bahwa ibu sudah sering bersikap keterlaluan kepada anak dan merupakan istri yang tidak pernah menghargai keputusannya sebagai kepala keluarga. Sementara anak lebih sering merasa bahwa sikap kedua orang tuanya tidak pernah memberikan kehangatan dan selalu saling menyalahkan.

Beberapa bulan berlalu, si anak melahirkan bayinya. Selama tinggal satu rumah dengan ayah ibu pasca menikah, keluarga ini sering kali mengalami perdebatan yang hebat. Suatu hari, saat dinas keluar kota, suami si anak mengirimkan chat yang berisi kalimat kasar kepada anak karena masalah suami istri. Ibu mengetahui isi chat tersebut, karena terbiasa membuka HP anak secara diam-diam kemudian tanpa ragu langsung memerintahkan anak untuk menceraikan suaminya. Ayah mencoba menenangkan ibu untuk tidak gegabah dalam meminta anaknya bercerai, namun ibu semakin marah karena merasa ayah tidak mendukung apa yang menjadi keputusannya. Anak dengan amarahnya langsung melawan perintah kedua orang tuanya dengan mengancam untuk melukai dirinya sendiri apabila tetap dipaksa. Namun ancaman itu tidak berhasil sehingga ibu tetap bersih keras untuk memerintahkan anaknya menceraikan suaminya. Merasa tidak sanggup, anak keluar dari rumah bersama bayinya dan menginap di kos-kosan di dekat tempat suaminya bekerja. Setelah anaknya kabur dari rumah bersama bayinya, kedua orang tua merasa sangat kebingungan dan merasa bersalah.

Hasil observasi pertama kali yang dilakukan di rumah menunjukkan bahwa hubungan antara ayah, ibu, dan anak adalah sedang tidak baik. Ibu nampak tidak mau memandang wajah anaknya, sementara ayah tidak memperlakukan anak demikian. Sikap sang anak kepada ibu dan ayahnya adalah sama-sama canggung dan sedikit berbicara, anak terlihat lebih sering menundukkan kepalanya disaat berbicara. Namun lamban laun suasana mulai mencair saat ayah, ibu, dan anak saling mengungkapkan apa yang mereka rasakan satu sama lain terkait dengan permasalahan yang mereka.

Dalam kasus ini, keluarga mengalami permasalahan dimana terjadi komunikasi yang kurang sehat antar anggota keluarga, yaitu ayah yang sering berusaha menenangkan amarah ibu namun selalu gagal karena kurangnya power yang dimiliki ayah, ibu selalu memaksakan kehendak kepada anaknya, sementara anak tidak mau mengalah dan lebih memilih untuk lari tanpa menyelesaikan permasalahan yang sedang dihadapi secara kekeluargaan sehingga tidak adanya komunikasi untuk menyelesaikan masalah tersebut. Permasalahan ini dapat dijelaskan dengan konsep teori keluarga yaitu sequence of interaction yaitu dengan ciri-ciri adanya rangkaian interaksi diantara para anggota keluarga yang saling memperkuat. Sequence of interaction adalah suatu rangkaian interaksi yang tidak tepat dan berlangsung terus-menerus sehingga memperburuk masalah keluarga (Geldard \& Geldard, 2011). Dalam kasus ini, ayah selalu mencoba menangkan ibu ketika ibu sedang meluapkan amarahnya kepada anaknya dengan cara 
apapun bahkan dengan berkata kasar sekalipun, namun respon ibu justru semakin meledak-ledak karena merasa bahwa ayah tidak berada di pihaknya, dengan semakin meledaknya amarah ibu kepada anak, maka anak semakin memberontak dengan bersikap tidak hanya melawan saja namun anak sampai memutuskan untuk kabur dari rumah.

Dinamika permasalahan keluarga dapat dijelaskan melalui General System Theory, dimana permasalahan muncul bukan dari masalah yang dimiliki oleh masing-masing anggota keluarga, melainkan berakar pada struktur hubungan dari sistem keluarga itu sendiri. Hubungan yang bermasalahan dalam sistem keluarga tersebut karena adanya konflik yang dialami dimana sistem tersebut tidak mampu menyelesaikannya. General System Theory oleh Bertalanffy ini memandang suatu keluarga adalah sistem secara keseluruhan, bukanlah kumpulan manusia yang terpisah. Teori ini tidak berfokus pada proses bagaimana permasalahan itu terjadi, namun berfokus pada untuk menyelesaikan masalah dari sistem dengan tujuan untuk mempersatukan sistem itu kembali (Von Bertalanffy, 1968).

Sequence of Interaction yang terjadi pada keluarga terbentuk karena masing-masing dari anggota keluarga memiliki memiliki peran dan melakukan hal yang saling mempengaruhi satu sama lainnya. Pengaruh yang muncul akibat dari proses ini adalah terbentuknya masalah tanpa ada solusi yang hadir menyertai, sehingga pola tersebut akan terus berlangsung apabila masing-masing anggota keluarga tidak merubah peran atau sikap yang selama ini mereka lakukan ketika menghadapi konflik baru. Dalam keluarga ini ayah memunculkan sikap yang berupaya untuk menenangkan ibu ketika ibu bersikap kasar kepada anak dengan cara apapun, bahkan dengan cara berkata kasar kepada ibu. Adapun respon yang dimunculkan oleh ibu adalah semakin marah kepada anaknya karena merasa suaminya tidak memihaknya dan lebih memihak kepada anaknya. Kemudian respon yang ditunjukkan oleh anak adalah semakin tidak terima dengan sikap yang dimunculkan oleh ibu, bentuk pemberontakan yang dilakukan oleh anak adalah melawan ibu secara verbal dan sampai mengambil keputusan untuk kabur dari rumah meninggalkan ayah dan ibunya. Dampak dari pola komunikasi yang membentuk sequence of interaction ini adalah menetapkan pola komunikasi yang tidak sehat sehingga tidak dapat menemukan solusi atas masalah yang sedang dialami oleh keluarga.

Dalam SFT, ada hal yang menjadi asumsi utama dalam menjalankan terapi. Terapi ini mengharuskan terapis untuk memiliki lensa baru dalam melihat Subjeknya. Terapis menggunakan kekuatan utama Subjek yaitu pemikirannya, kalimat dan juga pendapat-pendapat Subjek, dan juga menggali kompetensi-kompetensi Subjek (Beyebach, 2009). Dalam prosesnya, Subjek dapat dibantu dengan self-fulfilling yang positif, yaitu dengan menampilkan hubungan langsung yang muncul antara merencanakan perubahan dan hasil nyata dari hal tersebut. Hal ini dapat dilakukan dengan membicarakan kesuksesan-kesuksesan di masa lalu, masa kini, dan juga masa yang akan datang (D'Abate, 2016).

Setelah Subjek mempelajari kesuksesan-kesuksesanya kembali, Subjek akan menyadari nilai dari perubahan kecil (execptions) sehingga Subjek akan lebih mengharapkan perubahan-perubahan lain, dan mulai mempercayai snowball effect, yaitu hal kecil dapat menjadi besar (Evans, Turner, \& Trotter, 2012). Subjek adalah ahli dalam hidupnya, sehingga solusi dari permasalahan sudah ada di dalam Subjek namun Subjek masih belum menyadari solusi tersebut. Mendalami execption pada Subjek akan menumbuhkan insight yang mengarah pada tindakan positif yang lebih besar bahkan lebih sering. Subjek memiliki komptensi-kompetensi yang dapat ditarik dalam proses terapi. Sebagai hasilnya, harapan dan kepercayaan diri dalam menemukan solusi permasalahan akan terbangun (Cheung, 2001).

Skema dasar terapeutik dalam SFT untuk memulai pada berbagai macam kasus adalah menumbuhkan usaha untuk membangun hubungan, mencoba bekerja dengan Subjek untuk mengklarifikasi tujuan yang ingin dicapai dari terapi pada masing-masing sesinya. Hal ini dilakukan dengan teknik miracle question atau pertanyaan yang berorientasi pada masa depan 
lainnya. Setelah hal ini selesai dilakukan, terapis dapat melakukan execptions yaitu keadaan dimana apabila masalah itu ada namun tidak terjadi, atau terjadi dengan derajat keparahan yang lebih rendah, dan juga scalling question dimana meminta Subjek untuk memberi rating pada perubahan yang dialami. Dengan kata lain, pemikiran lebih digunakan untuk membangun solusi daripada sekedar memecahkan masalah saja (de Shazer \& Molnar, 1984).

\section{Diagnosis dan Prognosis}

Berdasarkan hasil asesmen yang dilakukan, diketahui bahwa keluarga mengalami maslaah Parental Child Realitional Problem (Z62.820). Hal ini berdasarkan diagnosis DSM-V dengan kriteria yaitu adanya kontrol orang tua yang berlebihan, tekanan berlebihan dari orang tua, penghindaran tanpa adanya resolusi dari konflik, serta kesedihan dan kemarahan untuk individu lain di dalam sistem keluarga.

Berdasarkan hasil asesmen, dapat diketahui bahwa keluarga memiliki motivasi dan komitmen yang tinggi untuk dapat menyelesaikan permasalahan yang mereka hadapi Sehingga dapat disimpulkan bahwa Subjek memiliki prognosis yang baik.

\section{Intervensi}

Solution Focused Therapy (SFT) dikembangkan oleh Steve de Shazer, Insoo Kim Berg dan tim mereka di pusat terapi keluarga di pertengahan 1980-an. Hal ini digambarkan sebagai terapi yang berfokus pada tujuan pengobatan dan dikembangkan dari terapi menerapkan pendekatan pemecahan masalah dan terapi keluarga sistemik (Gingerich \& Eisengart, 2000). Elemen kunci dari SFT meliputi; identifikasi masalah dan motivasi; miracle questions; kemungkinan/harapan; Scaling / tujuan pembentukan; exceptions; keyakinan/kekuatan; dan feedback.

Walter and Peller (2000) memberikan 3 pertanyaan solution-focused yang dapat membawa Subjek pada cerita sukses mereka. Pertanyaan pertama adalah "bagaimana anda melakukan hal tersebut?". Pertanyaan ini berangkat dari asumsi bahwa pada nyatanya Subjek telah melakukan sesuatu yang diwujudkan dalam tindakan, kompetensi, dan tanggung jawab. Pertanyaan kedua adalah, "bagaimana anda memutuskan untuk melakukan hal tersebut?". Pertanyaan kedua ini berangkat dari asumsi bahwa Subjek telah mengambil keputusan yang aktif untuk masa depannya dalam menyelesaikan masalah. Pertanyaan ketiga adalah, "bagaimana cara anda memanage untuk melakukan hal tersebut?". Pertanyaan ini membuat Subjek terhubung kembali dengan kesuksesan yang telah diraihnya. De Shazer and Berg (1985) menemukan bahwa ada tiga tipe spesifik dari perilaku terapis yang akan memunculkan hasil yaitu Subjek dapat mengungkapkan solusi dan melakukan perubahan, yaitu dengan pertanyaan mendetail terkait penerapan pemecahan masalah dan juga reward secara verbal karena Subjek telah menemukan suatu solusi.

Sesi 1.Kegiatan yang dilakukan adalah identifikasi masalah \& asesmen kesiapan untuk berubah. Tujuan dari kegiatan ini adalah untuk mengetahui permasalahan Subjek secara mendalam dan juga kesiapan anggota keluarga untuk berubah. Terapis melakukan asesmen penggalian masalah Subjek dengan fokus masalah yang dihadapi oleh keluarga dan juga mengidentifikasi kesiapan masing-masing anggota keluarga untuk berubah dengan scalling. Respon yang dihasilkan pada sesi ini adalah gambaran lebih dalam permasalahan yang dialami, sudut pandang dari ayah, ibu, dan anak ketika menghadapi suatu konflik dan harapan masing-masing saat menghadapi konflik, serta kesiapan untuk berubah yakni pada angka 10.

Sesi 2. Kegiatan yang dilakukan adalah Begin Seeing Solutions. Tujuan dari kegiatan ini adalah untuk membantu Subjek untuk melihat solusi-solusi yang dapat mereka temukan dalam menyelesaikan permasalahan keluarga. Terapis mengarahkan keluarga untuk mengkonstruk solusi yang mampu mereka buat dengan mengajukan beberapa pertanyaan terbuka yang mengarah pada untuk mengkonstruk solusi. Pertanyaan diajukan untuk masing-masing anggota 
keluarga dan diminta untuk saling menanggapi jawaban satu sama lainnya. Respon dari sesi ini adalah masing-masing anggota keluarga menjawab pertanyaan secara bergantian terkait dengan pertanyaan yang diajukan oleh terapis. Pada sesi ini, keluarga mengkonstruk satu solusi dari permasalahan yaitu jika ayah berusaha menenangkan ibu, ibu harus mendengarkan pendapat ayah karena ayah adalah kepala keluarga, lalu tidak boleh ada anggota keluarga yang keluar dari rumah (kabur) saat mengalami konflik dan tidak boleh ada anggota keluarga yang berbicara dengan nada tinggi pada satu sama lainnya. Tidak boleh ada anggota keluarga yang terlalu mencampuri urusan pribadi anggota keluarga lainnya (ibu mencampuri urusan rumah tangga anak). Dan ketika terjadi masalah serupa di masa yang akan datang, salah satu anggota keluarga harus saling mengingatkan dampak negatif dari masalah ini, yaitu anak kabur dari rumah bersama bayinya.

Sesi 3. Kegiatan yang dilakukan adalah Find GEMS; Goals, Exceptions, Miracle Questions, Scalling, And Homework. Tujuan sesi ini adalah untuk mengidentifikasi solusi lain dari permasalahan yang dialami oleh keluarga. Terapis mengarahkan semua anggota keluarga untuk mengidentifikasi ulang tujuan dan keinginan masing-masing anggota keluarga terhadap satu sama lain. Terapis mengarahkan keluarga untuk mendiskusikan tentang exceptions dari permasalahan yang mereka alami, terapis mengarahkan keluarga untuk berdisukusi yang berdasarkan pada miracle questions, terapis mengarahkan keluarga untuk memberikan penilaian berupa scale untuk menilai seberapa besar harapan dan kesuksesan yang nanti mereka peroleh untuk menyelesaikan permasalahan keluarga mereka, terapis memberikan homework berupa menuliskan bagaimana reaksi diri mereka sendiri saat ada anggota lain yang masih menerapkan pola komunikasi yang sama. Respon pada sesi ini adalah Tujuan yang ingin mereka capai adalah untuk dapat saling menghargai satu sama lain. Execptions; jika masalah ini tidak terjadi maka tidak ada anggota keluarga yang pergi dari rumah, dan rumah tangga akan menjadi tentram. Miracle Question; hal kecil pertama yang menjadi tanda bahwa masalah kami selesai adalah di pagi hari kami memulainya dengan sarapan bersama, bersenda gurau, dan saling memeluk satu sama lain. Scalling; semua anggota keluarga memberikan penilaian angka 10.

Sesi 4. Kegiatan yang dilakukan pada sesi ini adalah Evaluation \& Surprise Task. Tujuan dari sesi ini adalah untuk mengevaluasi homework dan memberikan arahan untuk melakukan surprise task pada masing-masing anggota. Terapis melakukan evaluasi mengenai tugas mereka terkait dengan sikap mereka dalam menghadapi masing-masing anggota keluarga. Kemudian terapis melakukan surprise task dimana meminta masing-masing anggota keluarga untuk saling memberikan kejutan/hadiah untuk satu sama lain berdasarkan dengan apa yang dibutuhkan atau yang diinginkan oleh masing-masing anggota keluarga. Respon pada sesi ini adalah hasil evaluasi homework adalah untuk ayah ia akan mengingatkan istri atau anak, untuk ibu ia akan mengalihkan dirinya yang mudah emosi dengan melakukan aktifitas yang lain terlebih dahulu lalu mengingatkan ayah dan anaknya, untuk anak ia akan mengingatkan ayah dan ibu resiko dari gaya komunikasi yang tidak sehat. Surprise task yang mereka pilih adalah, ayah memilih memberikan mukenah kepada ibu dan memberikan pakaian untuk anak. Sementara ibu memilih memberikan jaket untuk ayah, dan memberikan alat make up untuk anak. Sementara anak memilih memberi susu penguat tulang untuk ayah, dan buku resep makanan untuk ibu.

Sesi 5. Kegiatan yang dilakukan pada sesi ini adalah Instill a Vission \& Feedback. Tujuan pada sesi ini adalah untuk mengarahkan masing-masing anggota keluarga untuk mendiskusikan kondisi dimana permasalahan yang mereka hadapi menjadi lebih baik dan memberikan feedback atas keseluruhan terapi. Terapis mengarahkan masing-masing anggota keluarga untuk membayangkan dan mendiskusikan bagaimana kehidupan mereka apabila mereka dapat menemukan solusi dari permasalahan yang mereka alami dan bagaimana cara mempertahankan kondisi tersebut. Kemudian terapis memberikan feedback atas hasil diskusi dan keseluruhan hasil terapi. Respon pada sesi ini adalah keluarga menghasilkan upaya untuk mempertahankan 
kondisi dimana tidak mengalami permasalahan yang sama, yaitu dengan mempertahankan sikap saling diam dan mengalah, serta menghindar apabila ada salah satu anggota keluarga yang mulai melakukan gaya komunikasi yang lama.

\section{Hasil Intervensi}

Berdasarkan hasil intervensi yang telah dilakukan, terdapat beberapa perubahan kondisi yang dialami oleh keluarga pada saat sebelum dan sesudah dilaksanakannya intervensi menunjukkan keluarga berhasil merubah pola komunikasi menjadi lebih sehat, yaitu yang ditunjukkan pada Tabel 1.

Tabel 1. Hasil Sebelum dan Sesudah Intervensi

\begin{tabular}{|c|c|}
\hline Pra Intervensi & Pasca Intervensi \\
\hline $\begin{array}{l}\text { 1. Ayah mencoba menenangkan ibu ketika } \\
\text { bersikap kasar kepada anaknya, namun } \\
\text { terkadang ayah juga besikap kasar kepada } \\
\text { ibu ketika mencoba memberitahu ibu. }\end{array}$ & $\begin{array}{l}\text { 1. Ayah menenangkan ibu tanpa berkata } \\
\text { kasar pada ibu. }\end{array}$ \\
\hline $\begin{array}{l}\text { 2. Ibu selalu marah ketika ayah } \\
\text { mencoba menenangkannya dengan kasar } \\
\text { dan semakin marah kepada anak. }\end{array}$ & $\begin{array}{l}\text { 2. Ketika ayah menasehati, ibu lebih } \\
\text { memilih diam dan mendengarkan ayah. }\end{array}$ \\
\hline $\begin{array}{l}\text { 3. Anak memberontak perlakuan kasar } \\
\text { dengan cara berkata kasar dan kabur dari } \\
\text { rumah. }\end{array}$ & $\begin{array}{l}\text { 3. Anak tidak berbicara kasar kepada } \\
\text { ayah dan ibu. }\end{array}$ \\
\hline
\end{tabular}

\section{Pembahasan}

Dinamika permasalahan keluarga dapat dijelaskan melalui General System Theory, dimana permasalahan muncul bukan dari masalah yang dimiliki oleh masing-masing anggota keluarga, melainkan berakar pada struktur hubungan dari sistem keluarga itu sendiri. Hubungan yang bermasalahan dalam sistem keluarga tersebut karena adanya konflik yang dialami dimana sistem tersebut tidak mampu menyelesaikannya. General System Theory oleh Bertalanffy ini memandang suatu keluarga adalah sistem secara keseluruhan, bukanlah kumpulan manusia yang terpisah. Teori ini tidak berfokus pada proses bagaimana permasalahan itu terjadi, namun berfokus pada untuk menyelesaikan masalah dari sistem dengan tujuan untuk mempersatukan sistem itu kembali (Von Bertalanffy, 1968).

Dalam proses pelaksanaan terapi, keberhasilan terapi tidak lepas dari motivasi internal para anggota keluarga. Selama proses terapi berlangsung, keluarga antusias untuk mengikuti sesi-sesi dalam terapi dengan cara mencatat hal-hal yang perlu dicatat. Antusiasme muncul setelah anak pulang kembali ke rumah setelah memutuskan untuk kabur bersama bayinya. Faktor eksternal yang berperan di dalam keberhasilan terapi adalah kejadian kaburnya anak dari rumah bersama bayinya menimbulkan perasaan bersalah yang luar biasa pada ayah dan ibu, serta anaknya sehingga semua anggota keluarga dapat mendalami setiap proses terapi dengan sungguh-sungguh.

Solution Focused Therapy dalam memperbaiki pola komunikasi keluarga adalah dengan membantu mengkonstruk solusi dari pola komunikasi yang tidak sehat. Solusi-solusi tersebut merujuk kepada pola komunikasi sehat seperti apa yang harus dimiliki keluarga. Poin penting dalam SFT adalah membantu Subjek mengkonstruk solusi dari masalah yang mereka miliki daripada berfokus pada masalah itu sendiri Dalam prosesnya, Subjek dapat dibantu dengan self-fulfilling yang positif, yaitu dengan menampilkan hubungan langsung yang muncul antara merencanakan perubahan dan hasil nyata dari hal tersebut. Hal ini dapat dilakukan dengan 
membicarakan kesuksesan-kesuksesan di masa lalu, masa kini, dan juga masa yang akan datang (D'Abate, 2016). Setelah Subjek mempelajari kesuksesan-kesuksesanya kembali, Subjek akan menyadari nilai dari perubahan kecil (execptions) sehingga Subjek akan lebih mengharapkan perubahan-perubahan lain, dan mulai mempercayai snowball effect, yaitu hal kecil dapat menjadi besar (Evans, Turner, \& Trotter, 2012). Subjek adalah ahli dalam hidupnya, sehingga solusi dari permasalahan sudah ada di dalam Subjek namun Subjek masih belum menyadari solusi tersebut. Mendalami execption pada Subjek akan menumbuhkan insight yang mengarah pada tindakan positif yang lebih besar bahkan lebih sering. Subjek memiliki komptensi-kompetensi yang dapat ditarik dalam proses terapi. Sebagai hasilnya, harapan dan kepercayaan diri dalam menemukan solusi permasalahan akan terbangun (Cheung, 2001).

Skema dasar terapeutik dalam SFT untuk memulai pada berbagai macam kasus adalah menumbuhkan usaha untuk membangun hubungan, mencoba bekerja dengan Subjek untuk mengklarifikasi tujuan yang ingin dicapai dari terapi pada masing-masing sesinya. Hal ini dilakukan dengan teknik miracle question atau pertanyaan yang berorientasi pada masa depan lainnya. Setelah hal ini selesai dilakukan, terapis dapat melakukan execptions yaitu keadaan dimana apabila masalah itu ada namun tidak terjadi, atau terjadi dengan derajat keparahan yang lebih rendah, dan juga scalling question dimana meminta Subjek untuk memberi rating pada perubahan yang dialami. Dengan kata lain, pemikiran lebih digunakan untuk membangun solusi daripada sekedar memecahkan masalah saja (de Shazer \& Molnar, 1984).

\section{Simpulan}

Solution Focused Therapy secara efektif dapat membantu keluarga untuk mengkonstruk solusi dari permasalahan yang dialami sebagai suatu sistem keluarga yang utuh tanpa melihat masing-masing anggota keluarga sebagai hal yang terpisah-pisah. Dengan teknik menetapan tujuan, execption, miracle question, dan scalling dapat membantu keluarga untuk menghasilkan pemikiran-pemikiran terkait dengan hal yang harus mereka lakukan dan tidak boleh mereka lakukan ketika menghadapi permasalahan serupa di masa yang akan datang.

\section{Referensi}

Beyebach, M. (2009). Integrative brief solution-focused family therapy: A provisional roadmap. Journal of Systemic Therapies, 28(3), 18-35.

Bigner, J. J. 2002. Parent-Child Relations: An Introduction to Parenting. Ed. ke-6. Upper Saddle River, New Jersey: Merrill Prentice Hall.

Cantwell, P., \& Holmes, S. (1994). Social construction: A paradigm shift for systemic therapy and training. Australian and New Zealand Journal of Family Therapy, 15(1), 17-26.

Cheung, S. (2001). Problem-solving and Solution-focused therapy for Chinese: Recent developments. Asian Journal of Counselling, 8(2), 111-128.

de Shazer, S., \& Berg, I. K. (1985). A part is not apart: Working with only one of the partners present. In A. Gurman (Ed.), Casebook of marital therapy. New York: Guilford Press

de Shazer, S., \& Molnar, A. (1984). Four useful interventions in brief family therapy. Iournal of Marital and Family Therapy,10, 297-304.

D'Abate, D. A. (2016). Use of solution-focused and family narrative approaches in working with high conflict families: Strategies and techniques that can be utilized in parenting coordination and co-parenting coaching. Journal of Child Custody, 13(4), 269-288.

Evans, P., Turner, S., \& Trotter, C. (2012). The effectiveness of family and relationship therapy: A Review of the Literature. Psychotherapy and Counselling Journal of Australia.

Gamble, T. K., \& Gamble, M. (2005). Contacts: Interpersonal communication in theory, practice, and context. Recording for the Blind \& Dyslexic.

Gingerich, W. J., \& Eisengart, S. (2000). Solution-focused brief therapy: A review of the outcome research. Family process, 39(4), 477-498.

Goldenberg, I. \& Goldenberg, H. 1985. Family Therapy: An Overview. New York: Sage

Goldenberg, H., \& Goldenberg, I. (2012). Family therapy: An overview. Cengage learning.

Kantor, D., \& Lehr, W. (1975). Inside the family: Towards a theory of family process. San Francisco: Josey-Bass. 
Koerner, A. F., \& Fitzpatrick, M. A. (2006). Family communication patterns theory: A social cognitive approach. Engaging theories in family communication: Multiple perspectives, 50-65.

Le Poire, B. A. (2006). Family communication: Nurturing and control in a changing world. Sage.

Simon, J. K., \& Berg, I. K. (1999). Solution-focused brief therapy with long-term problems.

Von Bertalanffy, L. (1968). General system theory. New York, 41973(1968), 40.

Walter, J. L., \& Peller, J. E. (2000). Recreating brief therapy: Preferences and possibilities. WW Norton \& Co. 